\title{
INVESTIGATING THE IMPACT OF SMS SPEAK ON THE WRITTEN WORK OF ENGLISH FIRST LANGUAGE AND ENGLISH SECOND LANGUAGE HIGH SCHOOL LEARNERS
}

Kristy Winzker, Frenette Southwood \& Kate Huddlestone

Stellenbosch University

This study examined the impact of SMS speak on the written work of English first language (L1) and English second language (L2) grade 8s and 11s. The aim was to establish whether these learners make use of features of SMS speak in their English written work. The participants, 88 learners from an English-Afrikaans dual medium school, completed questionnaires from which the frequency and volume of their SMS use were determined, as well as the features of SMS speak they reportedly use while SMSing. In addition, samples of their English essays were examined for the following features of SMS speak: (deliberate) spelling errors; lack of punctuation; over-punctuation; omission of function words; and use of abbreviation, acronyms, emoticons and rebus writing. The questionnaires indicated that these learners are avid users of the SMS. All participants reported using features of SMS speak in their SMSes, and more than 40\% reported using SMS speak in their written school work. Despite this, features of SMS speak infrequently occurred in the written work of the learners, which could indicate that the learners are able to assess when it is and is not appropriate to use a certain variety of language. That said, a number of SMS speak features were indeed present in the samples, which indicates that SMS speak had some impact on the written work of these learners. Not all of the nonstandard features of their written English could, however, necessarily be attributed to the influence of SMS speak; specifically some of the spelling and punctuation errors could have occurred in the written English of high school learners from before the advent of cell phones.

\section{INTRODUCTION}

The 1990s saw a significant development in the mobile phone industry, with the introduction of the Short Message Service (SMS), also referred to as text messaging or texting. This allows for communication at a cost that is less than that of a phone call, offering more privacy and allowing users to communicate without being disturbed or disturbing those around them (Crystal, 2001:229). According to Thurlow (2003), there were almost one billion cell phone users worldwide in 2003, compared to the estimated 600 million people who used the internet at that time. In May of 2003 alone, 1.7 billion SMS messages, or so-called SMSes, were exchanged in Britain alone, which adds up to some 13 billion messages per year. In South Africa, the use of cell phones has been on the rise for more than a decade, and with the introduction of cell phone applications such as MXit, ${ }^{1}$ many South Africans, especially young people, are SMSing every day. 
The limit of 160 characters per SMS (Thurlow, 2003:5) has motivated users to invent spacesaving strategies in order to make SMSing quicker and more cost-effective, as exceeding this limit results in the user paying for sending an extra SMS. These space-saving strategies (to which we return in more detail later) include a significant amount of abbreviation, and creative use of punctuation and symbols. Much has been written about the increased use of SMS communication and the subsequent rise of so-called Textese or SMS speak. This way of using language has its origins in the language of the internet, using many of the features that are found in internet chat groups.

The language of the internet, referred to by Crystal as Netspeak, relies on characteristics of both speech and writing. Netspeak shares characteristics with writing in the way that Netspeak functions as a database system; for example, it has archives and advertising (Crystal, 2001:28). Many varieties of text can be found on the internet - literary, scientific, religious, etc. The writers who post their work or thoughts on the internet are similar to authors of books and of other written texts in that they do not know who their readership will be. Netspeak also shares characteristics with speech. This can be seen in the way communication takes place in chat groups and interactive services, e-mail, and virtual worlds on the internet. These interactions are similar to speech, as there is the expectation of an immediate response to messages that have been sent. Furthermore, like speech, these interactions are not permanent; they can be replaced, deleted or lost. There are also characteristics of face-to-face interactions in the style of what is typed - highly informal and conversational, making use of specific means to convey emotions and feelings.

Given the above, Netspeak can be described as writing that looks like speech, or 'talking in writing' (Collot \& Belmore, 1996:14). In other words, participants 'must use language as if they were having a conversation, yet their message must be written' (Collot \& Belmore, 1996:14). While Netspeak may resemble speech, it also differs from speech in several respects, one of which is that, in Netspeak, there is an absence of paralinguistic cues which are found in speech (Crystal, 2001:34). In Netspeak, the lack of hand gestures, facial expressions and tone of voice is replaced by the creative adaptation of spelling, punctuation and capitalisation (Werry, 1996:57), and in this process many of the traditional rules of grammar and style are ignored (Thurlow, Lengel \& Tomic, 2004:124). This creative use of symbols and spacing serves to convey meaning and emphasis. This can be seen in the way in which letters are repeated (as in oooops) and in the repetition of punctuation marks (as in hello!!!!) (Crystal, 2001:34), as well as in the use of capitalisation for emphasis (Thurlow et al., 2004:125).

Other features of Netspeak make communication on the internet speech-like, and enable short, quick responses that resemble turn-taking in face-to-face conversation. These features of Netspeak (which have now been adopted into SMS speak) include (1) the use of word compounds and blends, e.g., weblish for web English; (2) the use of abbreviations and acronyms, e.g., ROFL for rolling on the floor laughing; (3) minimal use of punctuation and capitalisation; (4) deliberate spelling errors; (5) fewer uses of traditional openings and closures such as Hello or Dear X; (6) the use of emoticons, or so-called smileys, e.g., (;) or :;; (7) the use of rebus writing, e.g., 2day instead of today; and (8) the exclusion of pronouns (Herring, 1996:3; Werry, 1996:54; Thurlow et al., 2004:125).

Because of the widespread and frequent use of cell phones, and in particular of the SMS, one could assume that people's written language may begin to show certain features that are used when writing SMSes, thereby no longer conforming to the generally accepted standards of 
written language. This was shown in a study by a Tshwane University of Technology student, Tamara Rodrigues. She found that 'the use of SMS had a negative effect on [tertiary - KF, FS \& KH] students' writing skills. They no longer used punctuation marks or capital letters' (Momberg, in The Sunday Independent, 12 November 2006). Rodrigues concluded that 'the influence of mobile phone messaging could not be denied any more'. Journalist John Sutherland expresses an extreme opinion when he comments that SMS speak 'masks dyslexia, poor spelling and mental laziness. Texting is penmanship for illiterates' (Guardian, 11 November 2002).

In one entry on the website txt2nite.com, where there is a forum for discussing various topics related to SMSing, a user points out that the SMS gives adolescents a 'medium that encourages them to explore and play about with the use of our language at a time when they are still learning about correct punctuation, grammar, and the overall structure of their syntax' (The Man of Txt, 2005:2). By using SMS speak, high school learners are making creative use of language, and this is taking place in an important phase of their language development, namely in the phase during which they need to acquire skills pertaining to formal written language. Also, due to the cost-efficiency and ease of SMSing and particularly of MXit, adolescents could be spending a substantial amount of time sending SMS and MXit messages, thus using SMS speak regularly and for increased periods of time. This prolonged use of SMS speak could affect the user's ability to shift between SMS language and standard written language. The concern is that learners who cannot, or who choose not to, switch between formally approved written language and SMS speak could find that they are penalised as they attempt to advance through the education system and into tertiary education. Therefore, it is important to understand the extent of the impact that SMS speak has on learners' school work.

This study aims to investigate the impact of frequent use of SMS speak on the written school work of high school learners in the English first language (L1) stream (henceforth called the 'English L1 learners', even though some of these learners may be from Afrikaans-speaking homes) and those in the English second language (L2) stream (henceforth 'English L2 learners'). The assumption is that SMS speak could lead to writing that displays features that deviate from standard written English as it is formally taught in high schools. The research question addressed in this study is the following: Which nonstandard features of English L1 high school learners' written English school work can be attributed to the frequent use of SMS speak? The five hypotheses of the study are outlined below:

Hypothesis 1: The majority of high school learners use SMS and/or MXit on a daily basis for a significant period of time. [If this is found to be the case, and if there are features of SMS speak in the learners' written work, then the presence of such features can sensibly be attributed to the frequent use of cell phone technology such as SMS and/or MXit.]

Hypothesis 2: High school learners use SMS/MXit mainly for social purposes (e.g., staying in touch with their friends, or chatting) and to a far lesser extent for other purposes, such as making arrangements with their parents, obtaining essential information or entering competitions. [In this study, learners were not asked with whom they use more SMS speak, i.e., with their parents or other adults or with their peers, and the manner in which learners possibly adapted their messages for different audiences (parents vs peers, for instance) were not examined. However, if Hypothesis 2 were found to be false - i.e., if it could be shown that a significant portion of high school learners' SMSes are not directed towards their friends, such differentiation in SMS style should have been investigated.] 
Hypothesis 3: Typical features of SMS speak are used by high school learners in their SMSes or when they use MXit. [Or, stated differently, high school learners are proficient and fast SMSers and/or users of MXit.]

Hypothesis 4: Typical features of SMS speak can be found in the written work of high school learners.

Hypothesis 5: L1 English learners use more features of SMS speak in their SMSes and in their written work than L2 English learners. [Afrikaans lends itself less to the use of certain SMS features (such as rebus writing; Weimers, 2008) than does English; therefore it is predicted that SMS features will also occur to a lesser extent in the written work produced by Afrikaans-speaking learners.]

\section{RESEARCH METHODOLOGY}

\section{General procedure}

Once permission for the study had been granted by the headmaster of an English-Afrikaans dual-medium high school in a middle-class area of Somerset West in the Western Cape and by the Western Cape Education Department, a questionnaire relating to SMS behaviour was devised (see below and the appendix). The headmaster was then requested to make available two grade 8 and two grade 11 classes (one English-medium and one Afrikaans-medium per grade) for the data collection process, in the hope that this would provide a balanced sample of high school learners: The grade 11s would have been exposed to the standards of high school English for longer than the grade 8s, thus their English writing skills would be expected to be better than those of the grade $8 \mathrm{~s}$. However, the grade $11 \mathrm{~s}$ would also have had more exposure to and experience with SMSing, which might prove to have had a greater influence on their written work.

The learners in these classes were given approximately 30 minutes to complete the one-page questionnaire, and they were asked not to consult with one another during the process. Prior to handing out the questionnaires, the purpose of the study was explained to all the participants, and they were informed that their participation was completely voluntary, that they would not be identifiable in the reporting of the results, and that the information they provided would be treated as confidential. All learners completed the questionnaire in full, and were given a letter to take home to their parents which provided information about the study and which gave them an opportunity to inform the school if they objected to their child's participation; however, none did so.

The English teachers of these classes were asked to provide samples of written work by the learners who completed the questionnaire. The teachers made the participants' English portfolios available, from which one-page samples were then photocopied and later analysed for features of SMS speak. These samples consisted of a page from an examination essay answer or a creative writing classroom assignment set for the subject of English, i.e., of writing in which the use of SMS speak would have been inappropriate. 


\section{Participants}

A total of 100 learners from the four classes were available on the day that the questionnaires were handed out; all 100 questionnaires were completed and handed in on the same day. Teachers provided samples of written work for 88 of the learners who had completed the questionnaire. The questionnaires of the 12 learners for whom no written sample could be obtained were discarded, and the 88 learners for whom written samples were available acted as participants in this study. Of these participants, 43 were in grade 8 and 45 in grade 11, while 51 were English L1 speakers and 37 were English L2 speakers.

\section{The questionnaire}

The questionnaire comprised five questions (see the appendix). The first two questions asked learners (1) how often they SMSed or used MXit, and (2) on the days on which they did make use of these services, how much time per day was spent SMSing or on MXit. Learners were also asked to give three reasons for their use of SMS. This was done to ascertain whether SMSing is used because it is necessary for communication and the transfer of important information, or whether it was a form of entertainment. This would provide a general idea of the motivation behind the use of SMS or MXit, which could explain the frequency of this particular kind of cell phone use.

The questionnaire furthermore asked learners whether they felt that SMSing and MXit had an effect on their written school work. They were asked to elaborate if they answered 'yes'. This question was asked in order to investigate learner's perceptions of the influence (if any) of SMSing and/or MXit on their written English.

Finally, learners were asked to indicate which of the following features of SMS speak could be found in their SMSes: spelling errors, lack of punctuation, over-punctuation, lack of function words, use of abbreviations or acronyms, use of emoticons, and the use of rebus writing. Each of these options was clearly explained and examples were given of each in order to avoid confusion or misunderstanding.

\section{Data analysis}

All the answers to each question in the questionnaires were tallied, first according to language group and then for all participants together. The samples of written work were analysed for actual features of SMS speak, and this was contrasted with the self-reported features, i.e., with the learners' perceptions of how SMSing and MXit influenced their written English. The list of features tallied in the written samples were the same as those which learners were asked to identify in their SMSes when completing the questionnaire, namely spelling errors, lack of punctuation, over-punctuation, lack of function words, and use of abbreviations or acronyms, emoticons and rebus writing. However, the analysis of the samples of written work produced a further three nonstandard features of English, namely shortening of words, slang, and colloquialisms. These SMS speak features (including the three just mentioned) were tallied according to the frequency with which they occurred in the samples from all four of the classes, but were also kept separate according to language group. 


\section{RESULTS AND DISCUSSION}

\section{Information obtained from the completed questionnaires}

\section{Frequency of using SMS and/or MXit}

In order to test Hypothesis 1 - which proposed that high school learners use SMS or MXit on a daily basis for a significant period of time - participants were asked to specify the frequency of SMS/MXit use, as well as the volume of usage. All 88 participants reported regular use of SMS or MXit for varying amounts of time; none of the participants went without SMSing or using MXit. As can be seen in Table 1, the majority of the participants in both language groups make use of SMS and/or MXit on a daily basis. The table also shows that a slightly higher percentage of learners in the L2 group than in the L1 group use SMS and/or MXit daily. Those participants who reported using SMS or MXit for more than four hours a day were in the minority: three from the L1 group and seven from the L2 group. Hypothesis 1 was thus borne out by the obtained data, implying that high school learners are frequently exposed to the features of SMS speak, whether in the messages that they send or in those that they receive.

Table 1: Frequency and volume of SMS or MXit usage

\begin{tabular}{|c|rl|rl|rl|}
\hline SMS/MXit usage & \multicolumn{5}{|c|}{ Number (percentage) of learners } \\
\hline Frequency & \multicolumn{2}{|c|}{ L1 learners } & \multicolumn{2}{|c|}{ L2 learners } & \multicolumn{2}{|c|}{ All } \\
\hline Daily & 31 & $(61 \%)^{*}$ & 26 & $(70 \%)$ & 57 & $(64 \%)$ \\
\hline A few times a week & 15 & $(29 \%)$ & 8 & $(22 \%)$ & 24 & $(27 \%)$ \\
\hline Hardly ever & 5 & $(10 \%)$ & 3 & $(8 \%)$ & 8 & $(9 \%)$ \\
\hline Never & 0 & $(0 \%)$ & 0 & $(0 \%)$ & 0 & $(0 \%)$ \\
\hline TOTAL & $51 \quad(100 \%)$ & 37 & $(100 \%)$ & 88 & $(100 \%)$ \\
\hline Number of hours per day & L1 learners & L2 learners & \multicolumn{2}{|c|}{ All } \\
\hline 0-1 hour & 32 & $(63 \%)$ & 16 & $(43 \%)$ & 48 & $(55 \%)$ \\
\hline $0-2$ hours & 15 & $(29 \%)$ & 4 & $(11 \%)$ & 19 & $(22 \%)$ \\
\hline $0-3$ hours & 1 & $(2 \%)$ & 7 & $(19 \%)$ & 8 & $(9 \%)$ \\
\hline $0-4$ hours & 0 & $(0 \%)$ & 3 & $(8 \%)$ & 3 & $(3 \%)$ \\
\hline More than 4 hours & 3 & $(6 \%)$ & 7 & $(19 \%)$ & 10 & $(11 \%)$ \\
\hline TOTAL & 51 & $(100 \%)$ & 37 & $(100 \%)$ & 88 & $(100 \%)$ \\
\hline
\end{tabular}

*Note: The percentages in parentheses are the percentages of learners who reported using SMS or MXit for that interval or length of time. In this case then, $61 \%$ of L1 learners said that they use SMS or MXit daily.

\section{Learners' reasons for using SMS or MXit}

The data in Figure 1 indicate the reasons participants gave for using SMS and/or MXit. Most participants (62 of the total of 88, or 70\%) indicated that talking to their friends was the major motivation for SMSing or using MXit. Adolescent social behaviour is characterised by 'increasing interest in, and involvement with, the peer group' (Louw \& Edwards, 1997:518). Therefore, friendships and friend groups are of high importance to them; they want to be connected to what is happening around them, they want to know where their friends are and what they are doing, and they want to be involved in social events. MXit and SMSing help fulfil this need for constant contact, because it is cost-effective, easy to use and readily available across all age and language groups.

The second most cited reason for using SMS and/or MXit (given by 46 participants, or 52\%) was to obtain information, which, in most cases, involved obtaining information about homework requirements. Other information that was sought included details about sporting 
activities. Making arrangements, such as planning social activities or arranging transportation with parents, as well as keeping in contact with friends and family, were also frequently cited as reasons for using SMS or MXit. Furthermore, almost a third of the participants (27 of the total of 88 , or $31 \%$ ) reported that they use SMSes and/or MXit because it is cost-effective, being cheaper than a phone call.

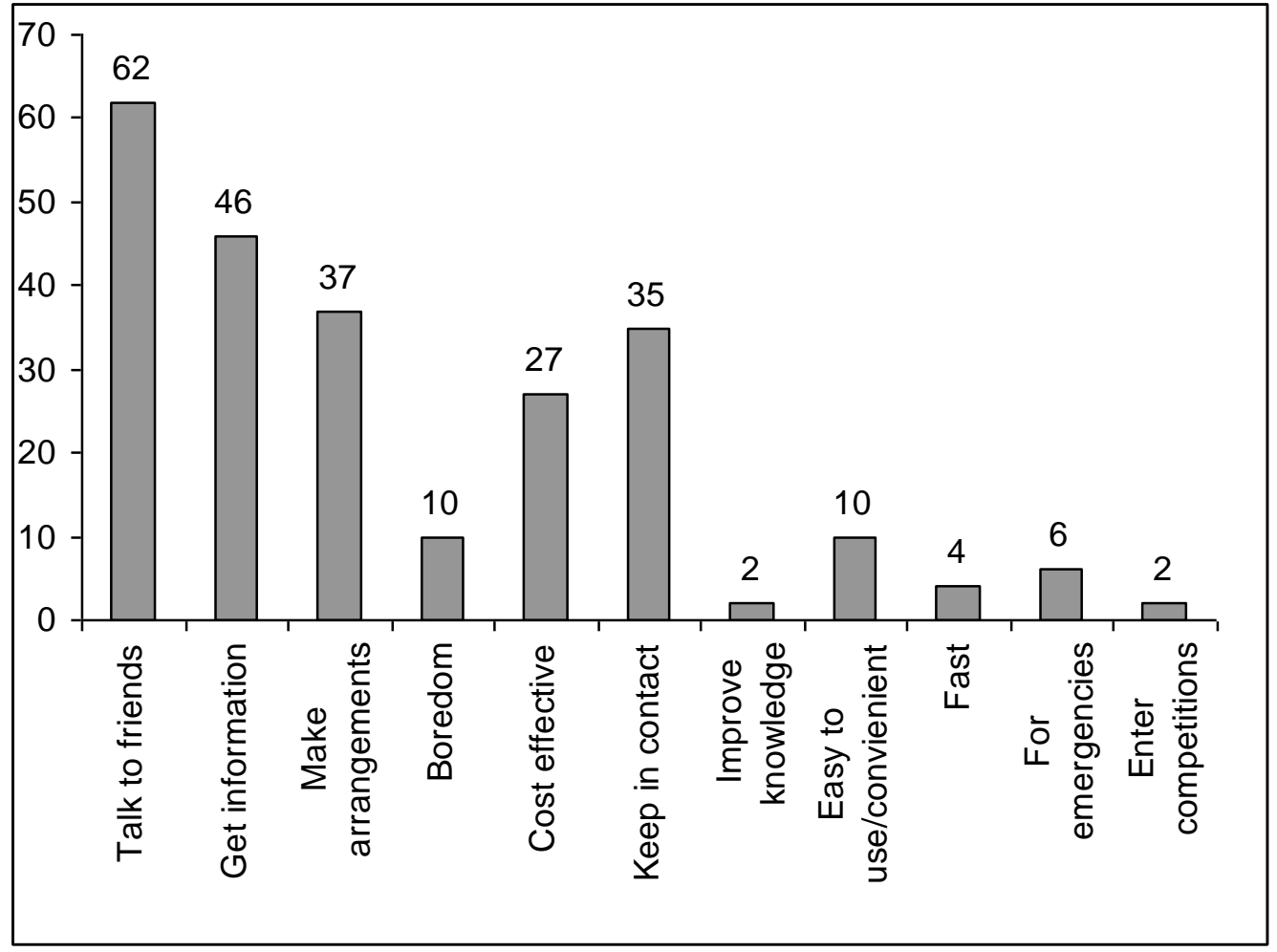

Figure 1: Reasons for using SMS/MXit (for both language groups combined)

Hypothesis 2 predicted that high school learners would be highly motivated to use SMS/MXit for social, but not for other, purposes. This hypothesis was partly borne out by the data: Although the participants used SMS/MXit for social purposes (e.g., keeping in contact with and talking to their friends), they also used SMS/MXit to obtain information and to make arrangements with their parents, amongst other reasons.

In Table 2, the two language groups are compared in terms of their self-reported reasons for using SMS and/or MXit. From this table, it can be seen that talking to friends was the reason most cited by both the L1 and the L2 learners (62\% and 81\%, respectively). This table also shows that there is not a significant difference in reasons for using SMS and/or MXit between the two language groups. The only noteworthy difference can be seen in the fact that there were no L2 participants who said that they use SMS or MXit because it is easy to use or because it is a quick means of communication, nor were there any who cited emergencies and entering competitions as reasons. 
Table 2: Reasons for using SMS/MXit, per language group

\begin{tabular}{|c|c|c|c|c|c|c|c|c|c|c|c|}
\hline 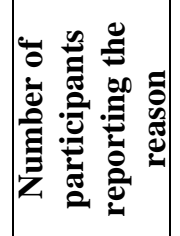 & 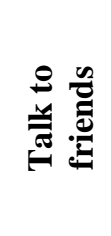 & Uू. & 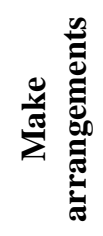 & 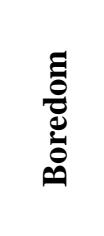 & 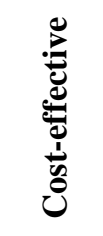 & 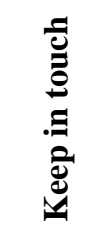 & 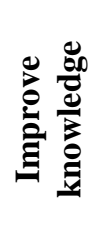 & 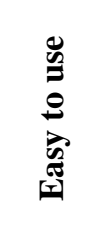 & $\begin{array}{l}\vec{y} \\
\vec{x} \\
\overrightarrow{\mid}\end{array}$ & 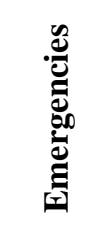 & \\
\hline L1 & $\begin{array}{c}32 * \\
(62 \%)\end{array}$ & $\begin{array}{c}26 \\
(50 \%)\end{array}$ & $\begin{array}{c}24 \\
(47 \%)\end{array}$ & $\begin{array}{c}4 \\
(7 \%)\end{array}$ & $\begin{array}{c}17 \\
(33 \%)\end{array}$ & $\begin{array}{c}23 \\
(45 \%)\end{array}$ & $\begin{array}{c}1 \\
(2 \%)\end{array}$ & $\begin{array}{c}8 \\
(15 \%)\end{array}$ & $\begin{array}{c}4 \\
(7 \%)\end{array}$ & $\begin{array}{c}6 \\
(11 \%)\end{array}$ & $\begin{array}{c}2 \\
(4 \%)\end{array}$ \\
\hline L2 & $\begin{array}{c}30 \\
(81 \%)\end{array}$ & $\begin{array}{c}30 \\
(81 \%)\end{array}$ & $\begin{array}{c}13 \\
(35 \%)\end{array}$ & $\begin{array}{c}6 \\
(16 \%)\end{array}$ & $\begin{array}{c}10 \\
(27 \%)\end{array}$ & $\begin{array}{c}12 \\
(32 \%)\end{array}$ & $\begin{array}{c}3 \\
(8 \%)\end{array}$ & $\begin{array}{c}0 \\
(0 \%)\end{array}$ & $\begin{array}{c}0 \\
(0 \%)\end{array}$ & $\begin{array}{c}0 \\
(0 \%)\end{array}$ & $\begin{array}{c}0 \\
(0 \%)\end{array}$ \\
\hline
\end{tabular}

*Note: Participants were allowed to give multiple answers to this question, therefore the frequency counts and percentages given in each cell in this table are independent of those in other cells.

\section{Features of SMS speak reportedly used in SMS and MXit messages}

In order to test Hypothesis 3, participants were given a list of features of SMS speak and asked to indicate which features they made use of when on MXit or when they sent SMSes. As can be seen in Figure 2, emoticons were reportedly the most used feature in SMSes and on MXit; 76 of the 88 participants $(86 \%)$ reported using this feature. Emoticons provide a convenient way to express the emotions and tone lost in text-only communication. They also take up less space in an SMS than a description of one's feelings would. If one were to attempt to explain a feeling like sadness, it would take up more space than the emoticon $\theta$, which also takes less time to type than I feel sad.

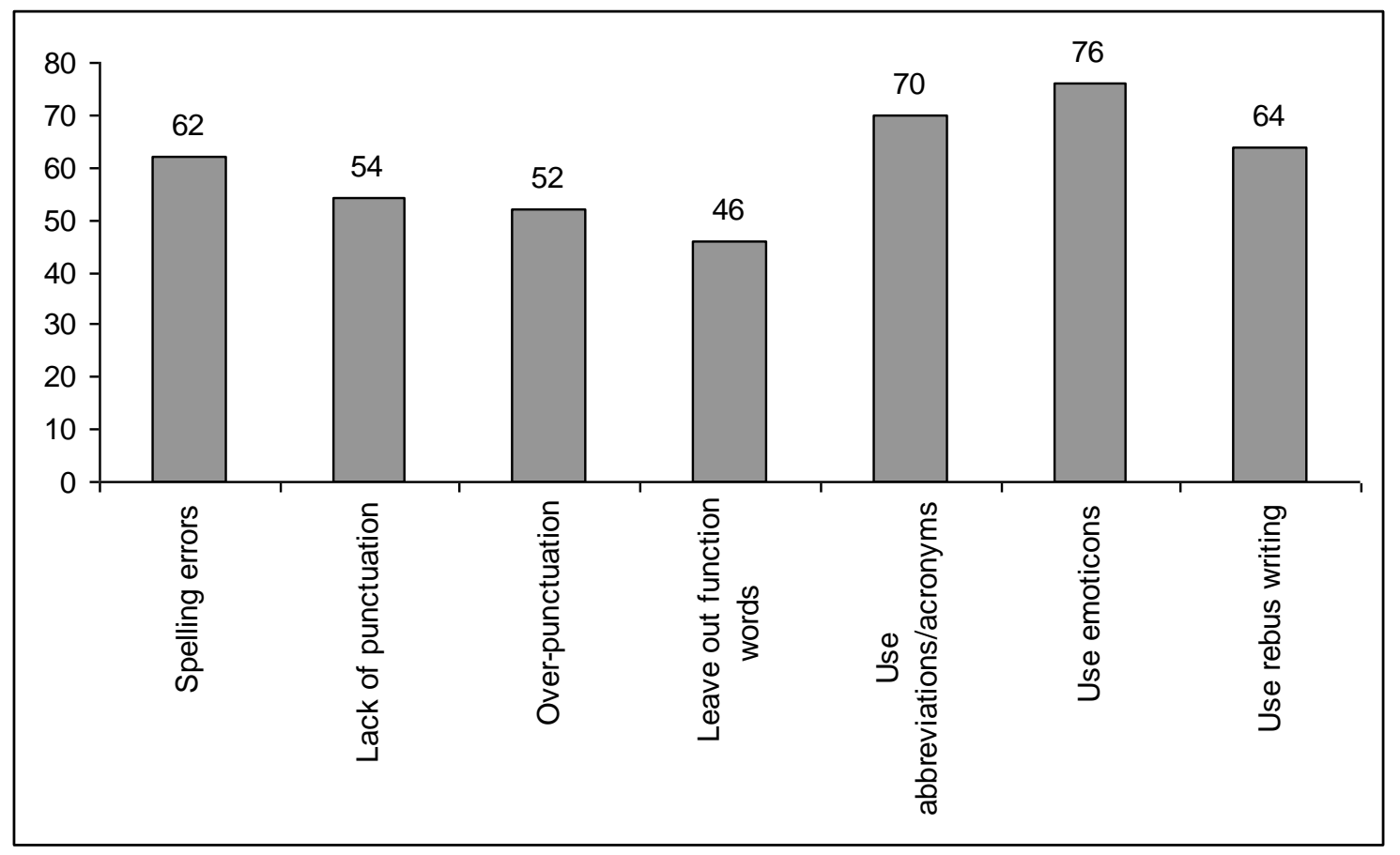

Figure 2: Self-reported features of SMS speak used in SMSes of all participants

As can also be seen from Figure 2, most of the participants (70 of the total of 88 , or $80 \%$ ) reported that they use abbreviations and acronyms in their SMSes or when on MXit, to allow them more typing space to convey their messages. The fourth most commonly used feature of SMS speak, after the use of rebus writing, was (deliberate) incorrect spelling, reported by 64 
participants (73\%). This can be linked to the fact that SMSes have space for only a limited number of characters, therefore SMS users will deliberately misspell a word if the incorrect spelling renders a shorter, but still comprehensible, version of the correctly spelled word. These self-reported features of SMS bear out Hypothesis 3: The participants of this study use most, if not all, of the identified features of SMS speak. Table 3 compares the two language groups in terms of their self-reported use of SMS features.

Table 3: Self-reported features of SMS use, per language group

\begin{tabular}{|c|c|c|c|c|c|c|c|}
\hline 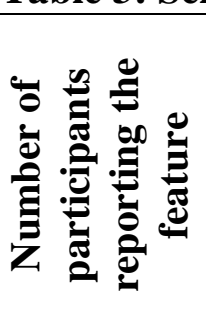 & 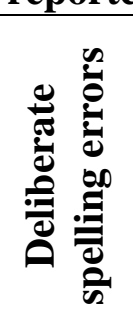 & 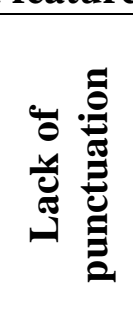 & 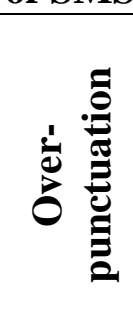 & 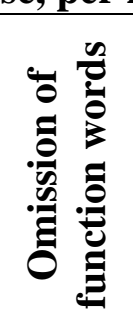 & 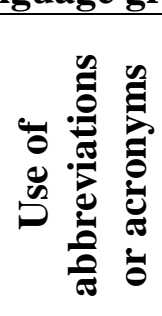 & 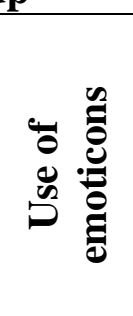 & 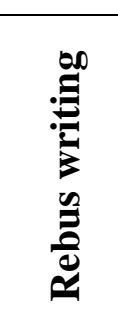 \\
\hline L1 & $\begin{array}{c}35 * \\
(68 \%)\end{array}$ & $\begin{array}{c}31 \\
(60 \%)\end{array}$ & $\begin{array}{c}29 \\
(56 \%)\end{array}$ & $\begin{array}{c}20 \\
(39 \%)\end{array}$ & $\begin{array}{c}42 \\
(82 \%)\end{array}$ & $\begin{array}{c}46 \\
(90 \%)\end{array}$ & $\begin{array}{c}39 \\
(76 \%)\end{array}$ \\
\hline L2 & $\begin{array}{c}27 \\
(72 \%)\end{array}$ & $\begin{array}{c}23 \\
(62 \%)\end{array}$ & $\begin{array}{c}23 \\
(62 \%)\end{array}$ & $\begin{array}{c}26 \\
(70 \%)\end{array}$ & $\begin{array}{c}28 \\
(75 \%) \\
\end{array}$ & $\begin{array}{c}30 \\
(81 \%) \\
\end{array}$ & $\begin{array}{c}25 \\
(67 \%) \\
\end{array}$ \\
\hline
\end{tabular}

*Note: Participants were allowed to give multiple answers to this question, therefore the frequency counts and percentages given in each cell in this table are independent of those in other cells.

As indicated in this table, the L1 speakers of English are more inclined to make use of certain SMS speak features - namely the use of abbreviations or acronyms, emoticons and the use of rebus writing - than the L2 speakers are, whereas more L2 speakers of English omitted function words than did L1 speakers. The use of deliberate spelling errors, lack of punctuation and over-punctuation were used to a comparable extent by the two language groups.

In a recent study by Weimers (2008:21), it was suggested that Afrikaans-speaking users of SMS were not able to make use of the same features of SMS speak as English speakers; in particular, the Afrikaans-speaking users were less likely to use rebus writing, as very few letter/number words in Afrikaans have a similar phonetic sound. For instance, in English, the pronunciation of four is the same as that of for, and therefore the number 4 can be used to replace both four and for when attempting to save space in an SMS. However, in Afrikaans, the pronunciation of vier differs significantly from that of vir ('for'), and therefore the number 4 cannot be used instead of the Afrikaans word for for.

To a certain extent, the results of this study support this explanation given by Weimers (2008:21), as the English L2 participants made less use of rebus writing than the English L1 participants. However, in general, the first part of Hypothesis 5 - that the L1 English learners will use more features of SMS speak in their SMSes than the L2 English learners - was not borne out by the data.

\section{Learners' perceptions regarding the presence of SMS features in their formal writing}

The majority of the participants (51 of the total of 88 , or 58\%) did not think that SMSing and/or MXit affected the language used in their written work. Those participants who believed that SMSing had an effect on their written work were asked to give specific examples. These participants reported that they struggled with correct spelling, made use of inappropriate abbreviations and acronyms, as well as shortened words. The results of the analysis of the participants' written work will be discussed in the next section, indicating that 
these (and other) features did indeed occur in the formal written English of the participants.

\section{Features of SMS speak found in the learners' written work}

Figure 3 indicates the nonstandard features of English that were identified in the samples of written work of the participants, and the number of samples in which each of these features were identified. The samples of written work were analysed for the previously identified features of SMS speak; however, during this analysis, there was a significant presence of features of SMS speak that had not been specified in the questionnaire (or reported in the literature). Figure 3, therefore, includes three additional features, namely slang, colloquialisms and shortening of words.

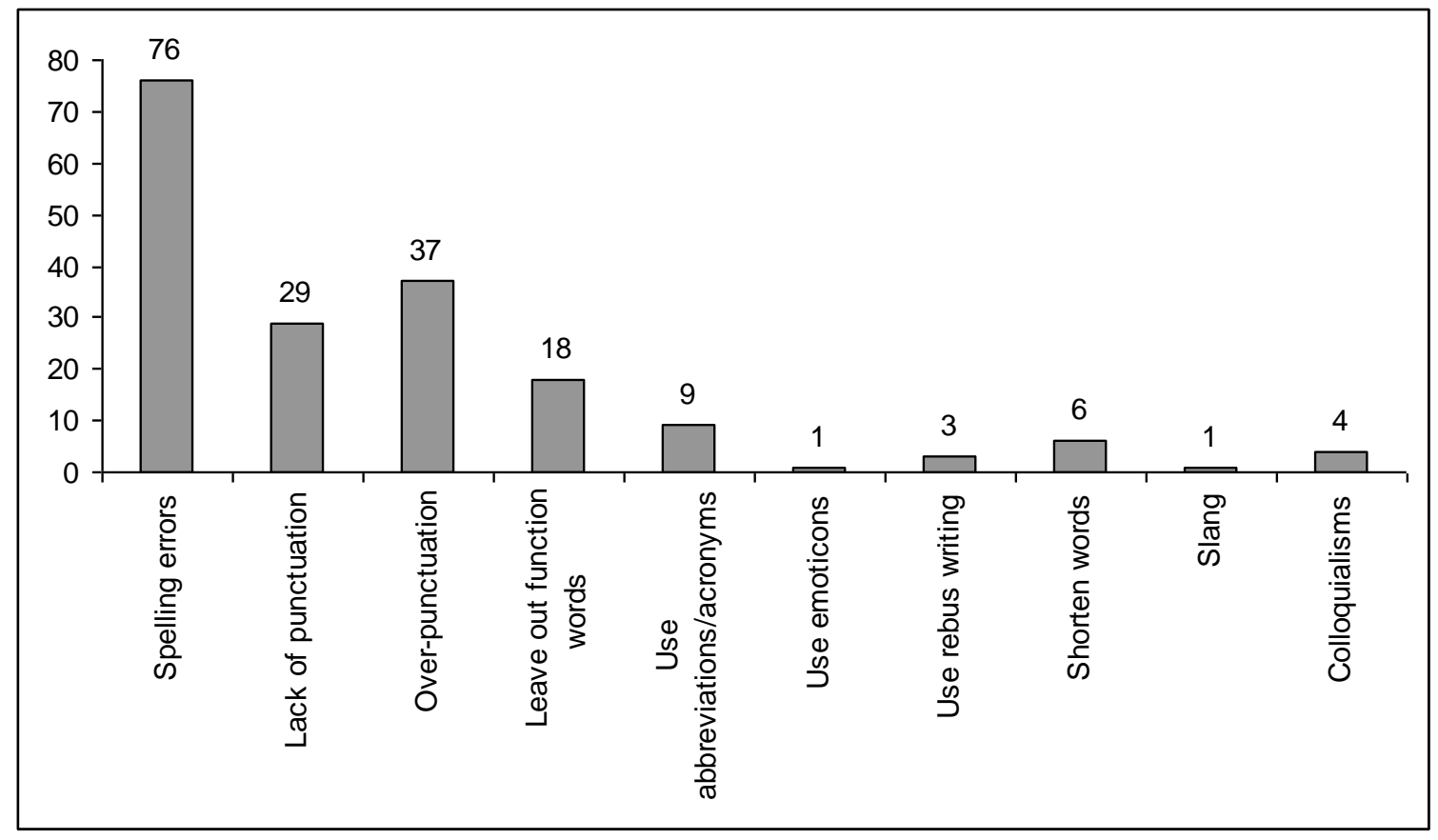

\section{Figure 3: Features of SMS speak identified in the samples of written work from all participants}

The most common feature of nonstandard English was incorrect spelling: Both language groups (and 76 of the 88 participants in total; 86\%) produced many examples of spelling errors, including grabed (for grabbed), wether (for whether), alot (for a lot), begginer (for beginner) and priveledged (for privileged). The first two examples of incorrect spelling might represent one of the additional features of SMS speak, namely shortening of words. Similarly, the omission of the space in the third example could have occurred for space-saving reasons. The last two examples are more than likely spelling errors unrelated to SMS speak.

The excessive use of punctuation was the second most prevalent feature of SMS speak in the samples of written work, with 37 of the 88 samples (42\%) including !!! as in Boof!!!, for example. Many examples of incorrect use or lack of punctuation were found (in $33 \%$ of the participants' written work), especially the lack of apostrophes. The following serve as examples of words that lack apostrophes: thats where the problem started, it wont be much fun and up and over Sir Lowrys Pass. The examples of lack of punctuation, such as question marks, full stops and commas include What is it about_, keep a fire extinguisher at hand_ and When_like we're used to_the lights went out!. Apart from being omitted, commas were also 
frequently used incorrectly, as shown in the following example: I went outside just to check but, I couldn't see them. There were very few examples of emoticons or rebus writing in the samples of written work. One participant made use of emoticons, for example drawing a smiley face at the end of a section of written work, and another participant used the number 2 instead of the word to in a sentence: Character reacting $\underline{2}$ others.

In addition, a significant number of examples of shortening of words occurred, although this feature was used by only 6 of the 88 participants (7\%). For example, one participant wrote $I$ need ur advice and another wrote cause her dad rides too fast for me and It felt like $a_{-}$ earthquake. Other participants provided examples of slang and colloquialisms (used by 1 and 4 of the 88 participants, respectively), as seen in we had the munchies (where the standard English version would be we were very hungry).

Comparing the two language groups, more L1 participants than L2 participants made use of nonstandard features of English in their written work, as can be seen in Table 4. This general result supports the second part of Hypothesis 5.

Table 4: Features of SMS speak found in samples of written work, per language group

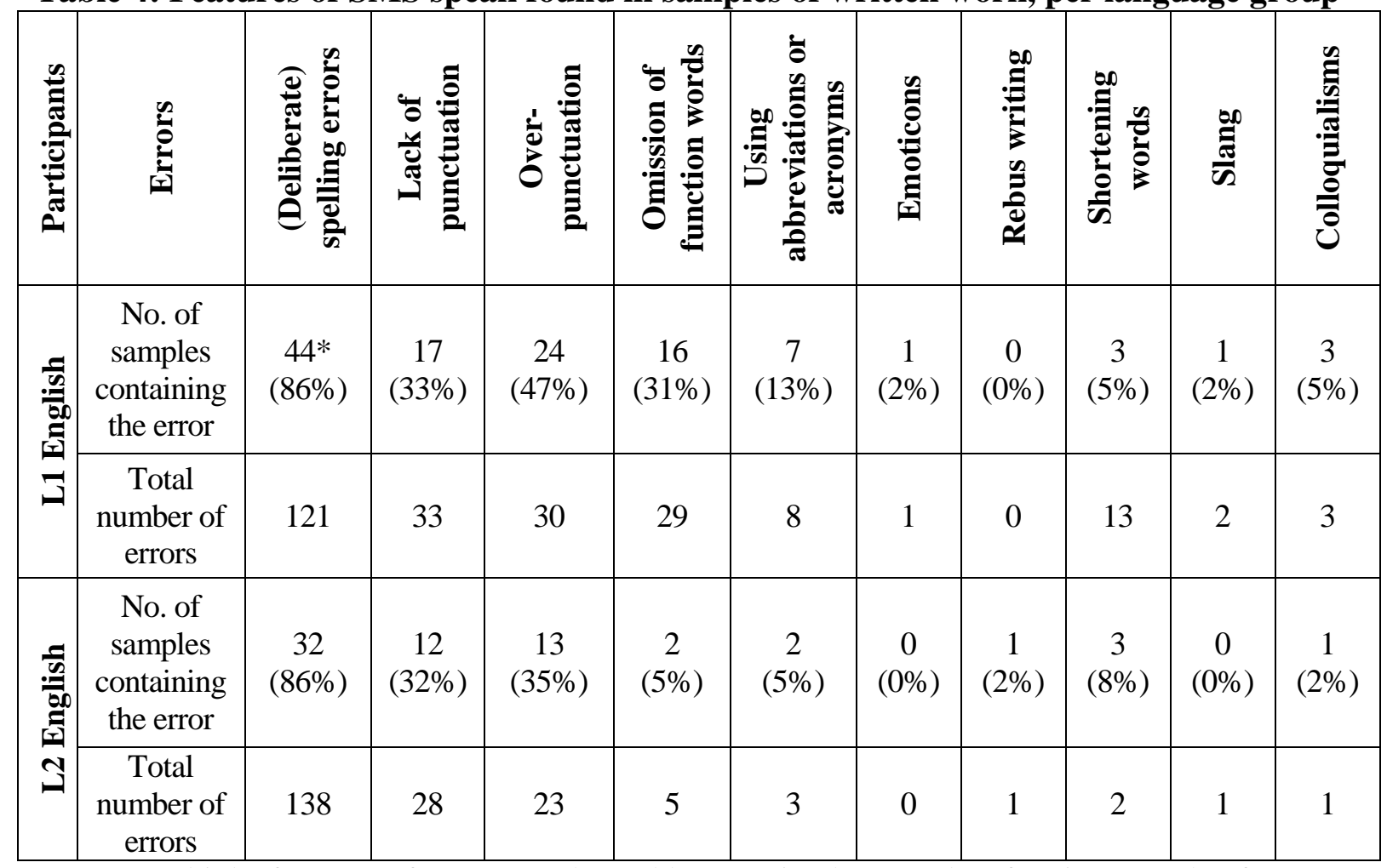

*Note: Multiple features of SMS speak could occur in the sample of written work of any one participant, therefore the frequency counts and percentages given in each cell in this table are independent of those in other cells.

Only word shortening and rebus writing were used by more L2 participants than L1 participants. The result concerning rebus writing was unexpected, given (1) that Weimers (2008:21) stated that Afrikaans lends itself less to rebus writing than does English (and therefore the L2 participants may have less experience with this SMS feature) and (2) that fewer L2 participants than L1 participants reported using rebus writing in their SMSes. In terms of spelling errors, lack of punctuation, and use of emoticons, slang and colloquialisms, the two language groups had comparable results. However, over-punctuation, omission of function words, and use of abbreviations and acronyms occurred in more of the L1 speakers' 
samples than L2 speakers' samples. This might be because the L2 participants find writing in their L2 more laborious than do the L1 participants, therefore paying more careful attention to what they are attempting to convey and to how they are formulating it, whereas writing in English is more 'automatic' for the L1 participants and therefore SMS features 'slip' into their language more easily than into that of the L2 participants.

It should furthermore be noted that the samples of written work produced by the L2 participants in this study may have been influenced by factors pertaining to transfer and/or interlanguage. The latter is defined by Ellis (1985:42) as 'the systematic knowledge of language which is independent of both the learner's L1 and the L2 system he is trying to learn'. The written work of the L2 participants revealed evidence of their L1 (Afrikaans) influencing their English. For instance, one L2 participant wrote we were busy watching this really nice movie, in which the direct translation of the Afrikaans phrase was besig occurs. Some incorrect uses of English in the written work of the L2 participants share similar features to SMS speak, such as certain spelling errors (e.g., welcom), shortening of words (e.g., opend or ur), and omission of function words (as in When you healthy you feel great). Therefore, it may be that some of the nonstandard features of English found in the L2 learners' written work could be attributed either to language transfer or to the influence of SMS speak.

\section{CONCLUSION}

Towards the end of the $20^{\text {th }}$ century, linguists and sociologists became interested in the impact of computer-mediated communication on language and society. In 1984, Baron (in Visible Language, 1984:139) stated that 'computer mediated communication might affect the existing forms and functions of spoken and written language'. Today, there is evidence that this has become a reality. Language is changing, and people are using language in different ways, be it on the internet or on their cell phones. We are, in a sense, 'shaped by technology but also shape it ourselves' (Thurlow et al., 2004:43), and this is apparent in the way that written language and spoken language are used differently today than they were only a few decades ago. This study showed that high school learners are avid users of SMS and/or MXit, and that all of these learners reported using features of SMS speak in their SMSes, with more than $40 \%$ reporting using SMS speak in their written school work.

It was surprising to find that, given the amount of exposure to SMS speak and the amount of time spent on compiling SMS and/or MXit messages, the samples of written work did not contain a far greater number of incidences of SMS speak features, particularly as teachers at this school had reported high incidences of rebus writing and emoticons in the written school work of their learners. There could be three explanations for this general finding: Firstly, the general absence of SMS speak in the written work of these learners could be a result of their ability to assess when it is and is not appropriate to use a certain variety of language. By this explanation, these learners are proficient style-shifters, being able to change from informal to formal speech or vice versa, depending on the situation (Yule, 2007:208): They are proficient in SMS speak and use it when chatting to friends in SMSes or on MXit, but they can produce written work that adheres to the generally accepted standards of written high school English when required to do so. Consider in this regard Crystal's discussion of audience consideration and how an awareness of who the recipient of the message is affects the language used by the learners: In an interview with John Crace (reported in The Guardian, 16 September 2006), 
Crystal is reported to have said 'Kids have a very precise idea of context - none of those I have spoken to would dream of using text abbreviations in their exams - they know they would be marked down for it.' Secondly, the lack of SMS features could be due to the type of written text chosen for investigation. Had general workbooks been chosen as texts, more SMS features might have been found, as these books are unlikely to be scrutinised by teachers. Thirdly, the learners in this study were attending a well-resourced school in a middle-class neighbourhood. As such, one could assume that they had been exposed to a reasonable standard of schooling throughout, and that this schooling would have included ample opportunity to practise writing and to make use of teacher feedback on their writing. Had the writing of learners from a different type of school (such as one in a township) been investigated, one might have seen more errors, the sources of which (SMS speak or general writing/spelling difficulties) would have had to be established.

However, a number of SMS speak features were discovered in the formal written work, which indicate that SMS speak indeed had some impact on the written work of the learners, which could, in turn, be attributed to the high frequency of SMS usage. However, not all of the nonstandard features of English could necessarily be attributed to the influence of SMS speak; many of these features could merely be evidence of problems with regard to applying formally-taught rules of English usage which have been noted among high school learners from before the advent of cell phones (such as spelling errors and difficulty with the correct use of the apostrophe and comma placement).

To conclude: Judging by the results of this study, there is little need for concern about the future of standard written English. As Thurlow et al. (2004:124) explain, 'Standard English may be the agreed norm for writing a college essay or a business letter, it's by no means the norm when speaking on the street - no one really speaks like they write! The internet is just one of many factors influencing the way language is changing.' Language change will continue to take place; it always has. Yet, with every major advancement in communication technology, there are those who bemoan the effect on language use. As Crystal (2004:81) observes, the present-day concerns surrounding SMS speak are not new: 'The apparent lack of respect for the traditional rules of the written language has horrified some observers, who see in the development an ominous sign of deterioration in standards. Text-messaging [i.e., SMSing - KF, FS \& KH] is often cited as a particular problem. Children in the future will no longer be able to spell, it is said. However, the fact that youngsters abbreviate words in textmessaging using rebus techniques (b4, CUl8er), initialisms (afaik "as far as I know", imho "in my humble opinion") or respelling (thx "thanks") is hardly new or fundamental. People have been using initialisms for generations (ttfn, asap, fyi) and rebus games have long been found in word-puzzle books.'

Crystal (2004:81) furthermore states that it is the responsibility of educators to impart knowledge and a sense of responsibility to their students, with regard to appropriate use of language. This seems to be the crux of the matter: SMS speak is informal and deviates from the standard written language that is formally taught in schools; however, adolescents although very proficient in SMS speak - do acquire a sensitivity towards different varieties of the languages which they speak during their time in the school system, and appear able to gauge the appropriate use of language in formal situations. 


\section{ACKNOWLEDGEMENTS}

This material is based on work financially supported by The National Research Foundation of South Africa. Any opinion, findings, conclusions or recommendations expressed are those of the authors and therefore the NRF does not accept any liability in this regard.

\section{END NOTE}

1. MXit is a program that can be downloaded onto a cell phone from the internet and makes instant messaging cheaper and more convenient. The cost is minimal (much less than SMSing) and the users benefit from instant, regular contact with whomever they choose, without needing to be online from a personal computer. MXit, reportedly, is used by more than 2 million users (Weimers, 2008:2), which is not surprising, as the cost of sending a message on MXit is substantially lower than a regular SMS from a cell phone: Sending a message on MXit costs 1 cent, compared to normal SMS rates which are charged at around 75 cents (Van Wyngaard in The Stellenbosch/Franschhoek/Pniel Gazette, 9 September 2008). MXit creator Herman Heunis explains that users are charged according to the amount of data sent in a message. This means that sending a message with a simple hello will cost around 0.0008 cents. If the same message was sent via regular SMS, the cost would be the same as when a 160-character long message is sent (Bouzaglou in The Mail and Guardian, 14 September 2006). The main advantages of using MXit include that it is easy to use and very cost-effective, and it provides users with the opportunity to be in contact with many friends simultaneously. It is much the same as chatting in an online chat room; however, MXit participants do not have to own a computer or have access to one; they can send messages wherever they are, at any time of the day, making use of their cell phone only.

\section{REFERENCES}

BARON, N. 1984. Computer Mediated Communication as a force in language change. Visible Language, XVIII(1):118-41.

BOUZAGLOU, H. 2006. Let's mix it cheaply, baby. Mail and Guardian, 14 September:7.

COLLOT, M \& N BELMORE. 1996. Electronic language: A new variety of English. In Herring, SC (Ed), Computer-Mediated Communication. Linguistic, social and crosscultural perspectives. Amsterdam: Benjamins. 13-28.

CRACE, J. 2008, September 16. Gr8 db8r takes on linguistic luddites [Online]. Available: http://www.guardian.co.uk/education/2008/sep/16/academicexperts.languages/print. [2009, 2 October].

CRYSTAL, D. 2001. Language and the Internet. United Kingdom: Cambridge University Press.

CRYSTAL, D. 2004. The Language Revolution. United Kingdom: Polity Press.

ELLIS, R. 1985. Understanding language acquisition. Oxford: Oxford University Press.

HERRING, SC. 1996. Introduction. In Herring, SC (Ed), Computer-Mediated Communication. Linguistic, social and cross-cultural perspectives. Amsterdam: Benjamins. 1-10.

LOUW, DA \& D EDWARDS. 1997. Psychology. An introduction for students in Southern Africa ( $2^{\text {nd }}$ edition). Johannesburg: Heinemann.

MOMBERG, E. 2006.SMS usage improves brevity but harms writing skills. The Sunday Independent, 12 November:5.

SUTHERLAND, J. 2002, November 11. Cn u txt? [Online]. Available: http://www.guardian. co.uk/technology/2002/nov/11/mobilephones2 [2008, 31 March]. 
THE MAN OF TXT. 2005. Are text messages making us illiterate? [Online]. Available: http://txt2nite.com/forum/viewtopic.php?t=43. [2008, $31 \mathrm{March}$ ].

THURLOW, C. 2003. Generation Txt? Exposing the sociolinguistics of young people's textmessaging [Online]. Available: http://extra.shu.ac.uk/daol/articles/v1/n1/a3/thurlow 2002003-paper. [2008, 31 March].

THURLOW, C, L LENGEL \& A TOMIC. 2004. Computer mediated communication: Social interaction and the Internet. London: Sage.

VAN WYNGAARD, M. 2008. Are you on MXit? The Stellenbosch/Franschoek/Pniel Gazette, 9 September 9:2.

WEIMERS, M. 2008. 2 Mix or nt 2 MIX? (Dats d kwestion): The effect of instant messaging on Afrikaans speaking adolescents in South Africa. Undergraduate research report, Division of Speech, Language and Hearing Therapy, Stellenbosch University.

WERRY, C. 1996. Linguistic and interactional features of Internet Relay Chat. In Herring, SC (Ed), Computer-Mediated Communication. Linguistic, social and cross-cultural perspectives. Amsterdam: Benjamins. 47-61.

YULE, G. 2007. The study of language. United Kingdom: Cambridge University Press.

\section{BIOGRAPHICAL NOTE}

Kristy Winzker has an interest in Applied Language Studies and youth work. Frenette Southwood and Kate Huddlestone are lecturers in the Department of General Linguistics at Stellenbosch University. Frenette works in language disorders and in second language acquisition, whereas Kate has an interest in the use of language in the media, as well as in electronic communication. Their email addresses are

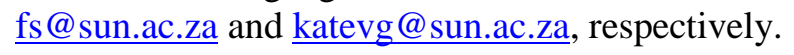




\section{APPENDIX: QUESTIONNAIRE ON SMS USAGE AND SMS SPEAK}

\section{Name}

Grade

What is your home language?

Do you own a cell phone?

Do you have MXIT on your phone?

How often do you SMS or use MXIT?

Daily

A few times a week

Hardly ever

Never

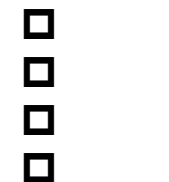

How much time do you spend SMSing or on MXIT a day?

$0-1$ hours a day

$0-2$ hours a day

$0-3$ hours a day

$0-4$ hours a day

more than 4 hours a day

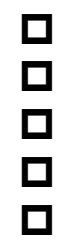

Give three reasons why you SMS:

1.

2.

3.

Do you think that SMSing or using MXIT affects the way you write at school?

Yes

No

If you answered yes, in what way does it affect your written work?

Which of the following do you use when SMSing or on MXIT:

Don't worry about spelling (e.g., make spelling mistakes)

Don't worry about punctuation (e.g., leave full stops and commas out)

Use more punctuation than is necessary (e.g., use lots of exclamation marks)

Leave out functional words (e.g., 'the', 'a' / 'an')

Use (lots of) abbreviations and acronyms

(e.g., 'LOL' for 'laugh out loud'; 'thx' instead of 'thanks')

Use smileys (e.g., :-( or $(-))$

Use letters or numbers to express the way a word/letter sounds (e.g., 'cu' / '18er') 